\title{
The effect of obesity on depression and excessive daytime sleepiness
}

\section{Obezitenin depresyon ve güindüz uykulluluk durumu üzerine etkisi}

\author{
Nur Demirloaș, Ruhușen Kutlu
}

Necmettin Erbakan Universitesi Meram Tip Fakültesi Aile Hekimliği AD, Konya,Türkiye

Corresponding author: Nur Demirbaş, MD, Necmettin Erbakan Üniversitesi Meram Tıp Fakültesi Aile Hekimliği AD, Konya,Türkiye

E-mail: ndemirbas76@hotmail.com

Received/Accepted: April 24, 2019 / July 01, 2020

Conflict of interest: There is not a conflict of interest.

\section{SUMMARY}

Objective: Excessive Daytime Sleepiness (EDS) is a tendency to sleeping with increased fatigue during the day, following insufficient sleep at night. The aim of this study was to determine the relationship between obesity on depression and excessive sleepiness and to investigate the factors affecting them in women.

Method: The study was conducted with 385 randomly selected female participants between the ages of 18-65 who applied to our family medicine outpatient clinic for any reason. Sociodemographic characteristics and body mass index (BMI) of the participants were recorded. The Hospital Anxiety Depression Scale (HADS) and the Epworth Sleepiness Scale (ESS) were used.

Results: The mean age of the participants were $37.24 \pm 10.7$ (18-63) years, mean BMI was $26.85 \pm 6.8 \mathrm{~kg} / \mathrm{m}^{2}$. The mean ESS score was $8.50 \pm 4.4$ point. According to the survey results of the HADS and ESS, obese women were found to have higher depression and daytime sleepiness than those with weak, normal and overweight and this difference was statistically significant $(\mathbf{p}<\mathbf{0 . 0 0 1})$. It was seen that $57.7 \%(n=60)$ of the 104 women with moderate / high ESS scores were obese, 20.2\% $(n=21)$ were overweight $(\mathbf{p}<\mathbf{0 . 0 0 1})$ and $82.7 \%(n=86)$ of these women had higher depression scores. As the BMI of the participants increased, there was an increase in depression symptoms and daytime sleepiness $(\mathbf{p}<\mathbf{0 . 0 0 1})$.

Conclusions: In our study, the prevalence of EDS in women was found to be $9.4 \%$. As the level of obesity and depression increased, the incidence of GAUH increased. Prevention of obesity, which has become a social problem considering the principle of Preventive Medicine, which is one of the basic features of Family Medicine, will prevent obesity related both depression and sleep disorders.

Keywords: Obesity, depression, excessive daytime sleepiness
Nur Demirbaş

Ruhuşen Kutlu

ORCID IDs of the authors:

N.D. 0000-0002-4038-9386

R.K. 0000-0002-8502-0232

\section{ÖZET}

Amaç: Gündüz aşırı uykululuk hali (GAUH) gece alınan yetersiz uykuyu takiben gün içerisinde artmış yorgunluk ile uykuya eğilimli olma durumudur. Bu çalışmada kadınlarda obezitenin depresyon ve gündüz aşırı uykululuk durumu ile ilişkisini belirlemek ve etkileyen faktörleri araştırmak amaçlandı.

Yöntem: Çalışma aile hekimliği polikliniğimize herhangi bir nedenle başvuran 18-65 yaş arası rastgele seçilen 385 kadın katılımcı ile yapıldı. Katılımcıların sosyodemografik özellikleri sorgulandı ve beden kitle indeksleri (BKI) kaydedildi. Hastane Anksiyete Depresyon Ölçeği (HADÖ) ve gündüz uykululuk halini belirlemek amacıyla Epworth Uykululuk Ölçeği (EUÖ) uygulandi. 
Bulgular: Kadınların yaș ortalaması 37,24 $\pm 10,7$ (18-63) yaș, BKİ ortalaması 26,85 $\pm 6,8 \mathrm{~kg} / \mathrm{m}^{2}$ Epworth uykululuk

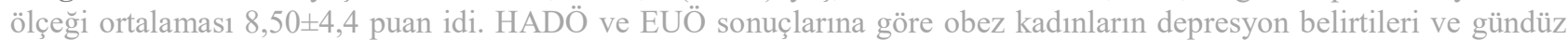
uykululuk düzeyleri, zayıf, normal ve aşırı kilolu olanlara göre daha yüksek bulundu ve bu fark istatistiksel olarak anlamlıydı (p<0,001). EUÖ puanı orta/yüksek bulunan 104 kadının \%57,7'si (n=60) obez, \%20,2'si (n=21) aşırı kilolu idi (p<0,001). Kadınların \%82,7'sinin (n=86) HADÖ'ne göre depresyon puanlarının yüksek olduğu görüldü. Katılımcıların BKI'leri arttıkça depresyon belirtilerinde ve gündüz uykululuk durumunda artma görülmekte idi $\left(\mathbf{R}^{2}=0,127, \mathbf{p}<0,001\right)$.

Sonuç: Çalışmamızda kadınlarda GAUH sıklığı \%9,4 olarak bulundu. Obezite ve depresyon düzeyi arttıkça GAUH görülme sıklığı da artıyordu. Aile Hekimliğinin temel özelliklerinden "Koruyucu Hekimlik" ilkesi göz önünde bulundurularak toplumsal bir sorun haline gelmiş obezitenin önlenmesi, obeziteye bağlı depresyon ve uyku bozukluklarının önüne geçecektir.

Anahtar sözcükler: Obezite, depresyon, gündüz aşırı uykululuk hali

\section{INTRODUCTION}

Obesity is an important health problem with an increasing prevalence in recent years. Obesity calculated with BKI is defined as excessive fat accumulation in the body. The Body Mass Index (BMI) is calculated by using height and weight values, $25-29.9 \mathrm{~kg} / \mathrm{m}^{2}$ are overweight, 30-39.9 $\mathrm{kg} / \mathrm{m}^{2}$ are obese, and $40 \mathrm{~kg} / \mathrm{m}^{2}$ and above morbid obese $^{1}$. In the TURDEP-II study, in which 26.499 people participated in 2010, the frequency of obesity in the Turkish adult society has found as $31.2 \%$. The frequency of obesity is $44 \%$ in women and $27 \%$ in men, and obesity has increased by $34 \%$ in men and $107 \%$ in women in the last 12 years $^{2}$. As a result of studies, it is known that obesity is associated with many chronic diseases such as type 2 diabetes, hypertension, stroke, cardiovascular diseases, sleep apnea syndrome ${ }^{2}$.

Excessive Daytime Sleepiness (EDS) is not a disease or disorder, but it is defined as a symptom of many primary sleep disorders. It is the most common symptom in sleep-related disorders. By definition; It means being tending to sleep with increased fatigue during the day following insufficient sleep at night ${ }^{3}$. Excessive daytime sleepiness is a common problem that clinicians too often encounter in their practice. In the studies conducted, the frequency of EDS was reported to be $22 \%$ in women and $17 \%$ in men and found to be associated with chronic diseases, occupational diseases and public safety hazards ${ }^{4}$. In the crosssectional studies, EDS has been shown to be associated with psychiatric, cardiometabolic and respiratory diseases, particularly depression, obesity and obstructive sleep apnea syndrome $(\text { OSAS })^{5}$.

EDS, which is a public health problem, is an independent risk factor for morbidity and mortality especially from cardiovascular diseases. There are studies that show that both decrease in night sleep time and excessive daytime sleepiness can increase the risk of death due to cardiovascular diseases ${ }^{6,7}$.

Obesity is associated with daytime sleepiness. In a study, EDS was observed in obese individuals twice more than non-obese individuals ${ }^{4}$. In some studies, it was found that the prevalence of poor sleep quality, snoring habit, sleep apnea, morning headaches and excessive daytime sleepiness in morbidly obese people was high and significant improvement in these symptoms has been found with weight $\operatorname{loss}^{8,9}$. Depression is strongly associated with sleepiness in both obese and nonobese people. However, it is accepted that $70 \%$ of those with depressive disorder have difficulty in starting and maintaining sleep, so daytime sleepiness caused by insomnia and fatigue is an important problem in this patient group.

In most of the clinical rating scales used for depression, information about excessive fatigue is not obtained, especially the effect of depression on EDS prevalence can be neglected. Therefore, in this presented study, we aimed to evaluate the relationship between obesity and depression and excessive daytime sleepiness in women and to investigate the factors affecting them.

\section{MATERIAL AND METHODS}

\section{The form of the research, the place and the data collection}

This cross-sectional study was conducted in 385 women aged 18 years and over who applied to the Family Medicine Outpatient Clinic for any reason. A questionnaire prepared by the researchers to determine the sociodemographic characteristics of the patients, Hospital Anxiety Depression Scale (HADS) to determine the state of anxietydepression, and Epworth Sleepiness Scale to determine daytime sleepiness were applied. Body mass indexes $\left(\mathrm{BMI}=\mathrm{Weight}(\mathrm{kg}) / \mathrm{Height}(\mathrm{m})^{2}\right)$ were calculated by taking the height and weight measurements of the patients included in the study. 


\section{Exclusion criteria}

Patients who are unable to communicate verbally, who do not have the mental capacity to understand and respond to the questionnaire, and who do not agree to participate in the study, as well as patients with known chronic illness, endocrine disorders psychiatric illness, previous sleep disturbance, oncological illness, patients undergoing surgical and medical treatment for obesity were also excluded.

\section{Ethical Authorisation of the study}

Before the study was started, an ethical approval was received from University Ethic Committee (Number: 2018/1544). Participants were initially informed about the study and their verbal consents were obtained according to the principles of the Helsinki Declaration.

\section{Hospital Anxiety Depression Scale (HADS)}

The Hospital Anxiety and Depression Scale (HADS) was used to determine the anxiety and depression status of the patients. HADS is a self rating scale developed by Zigmoid and Snaith (1983) to determine the risk for anxiety and depression ${ }^{10}$. The purpose of the scale is not to diagnose but to determine the risk group by scanning anxiety and depression in those who have physical illnesses in a short time. Seven of the questions in the scale investigates depression, and 7 answers anxiety symptoms. The responses are rated in 4-point likert and scored between 0-3. There are Anxiety (HAD-A) and depression (HAD-D) subscales. As a result of a study in Turkey, cut-off score for anxiety subscale was found to be 10/11, and for the depression subscale it was found to be $7 / 8$. The HADS was used to determine the anxiety and depression status of the patients. Turkish reliability and validity study of the scale was made by Aydemir et al ${ }^{11}$.

\section{Epworth Sleepiness Scale (ESS)}

ESS was developed by Johns in 1991 and is used to assess daytime sleepiness. This scale, Izci et al. (2008) has been adapted to Turkish by conducting validity and reliability analyses ${ }^{12}$. The scale is of a quadruple Likert type feature and is rated 0-3 and shows high score is sleepiness. The test is considered normal between 0-9 points, mild / moderate $10-15$ points, and severe severity between 16-24 points. Unlike other scales, the ESS assesses whether patients have daytime sleepiness and questions the predisposition to sleep during 8 daily activities ${ }^{3}$.

\section{Statistical Analysis}

The results of the study were evaluated and the program SPSS (Statistical Package for Social Sciences) for Windows 20.0. Frequencies, mean, standard deviation, median, minimum and maximum values, Odds ratios were calculated. Chi-square test was used to compare qualitative data. Compatibility with normal distribution was evaluated by Kolmogorov-Smirnov test. Accordingly, differences between the mean were determined by Student t-test, one way ANOVA variance analysis. The level of significance was considered $\mathrm{p}<0.05$.

\section{RESULTS}

The mean age of 385 female patients who agreed to participate was $37.24 \pm 10.7$ (18-63) years, $70.4 \%(\mathrm{n}=271)$ were married and $53.5 \%(\mathrm{n}=206)$ secondary educated and below, and $56.9 \%$ $(n=219)$ were housewives. The mean BMI of the participants was $26.85 \pm 6.8 \mathrm{~kg} / \mathrm{m}^{2}, 31.2 \%(\mathrm{n}=120)$ were obese and $27.3 \%(n=05)$ were overweight.

When the results of the HAD scale are evaluated; The mean score of anxiety was $8.36 \pm 3.7$, and the mean score of depression was $10.39 \pm 4.2$ points. According to the cutoff points of the scale, $24.4 \%$ $(\mathrm{n}=94)$ of the participants had symptoms of anxiety, while $72.5 \% \quad(\mathrm{n}=279)$ had symptoms of depression. The mean score of ESS was $8.50 \pm 4.4$ points.

While the sleepiness level of women was normal in $72.9 \%$, moderate sleepiness was found in $17.7 \%$ and severe sleepiness was in $9.4 \%(n=36)$. In women with secondary school and below educated, married and housewives, the EDS score was statistically significantly higher than single, highly educated and working women $(\mathbf{p}=\mathbf{0 . 0 0 3})$.

When BMI was compared with HAD-A, HAD-D and ESS; depression and daytime sleepiness scores was found higher in obese people than weak, normal, and overweight women. This relationship between the groups was statistically significant $(\mathbf{p}<\mathbf{0 . 0 0 1})$ (Table 1). 
Table 1: Comparison of HAD-A, HAD-D and ESS according to BMI

\begin{tabular}{|l|c|c|c|c|c|}
\hline & Underweight & Normal & Overweight & Obese & \\
\hline & mean \pm SD & mean \pm SD & mean \pm SD & mean \pm SD & p $^{* 1}$ \\
\hline Age(year) & $26.83 \pm 6.9$ & $36.62 \pm 10.6$ & $40.06 \pm 9.3$ & $40.48 \pm 10.1$ & $<\mathbf{0 . 0 0 1}$ \\
\hline HAD-A & $8.43 \pm 4.1$ & $8.24 \pm 3.6$ & $7.97 \pm 3.6$ & $8.78 \pm 3.8$ & 0.450 \\
\hline HAD-D & $9.22 \pm 4.1$ & $9.39 \pm 4.0$ & $10.13 \pm 4.2$ & $12.03 \pm 3.8$ & $<\mathbf{0 . 0 0 1}$ \\
\hline ESS & $7.0 \pm 3.0$ & $7.29 \pm 2.9$ & $7.36 \pm 3.3$ & $11.26 \pm 5.4$ & $<\mathbf{0 . 0 0 1}$ \\
\hline
\end{tabular}

*One-way Anova

BMI:Body Mass Index, HAD-A:Hospital Anxiety-Depression-Anxiety, HAD-D:Hospital Anxiety-Depression Depression, ESS: Epworth Sleep Scale

Table 2: Comparison of BMI, anxiety and depression status according to EES

\begin{tabular}{|c|c|c|c|c|c|c|}
\hline & & \multicolumn{2}{|c|}{$\begin{array}{c}\text { ESS:0-9 point } \\
\text { Normal }\end{array}$} & \multicolumn{2}{|c|}{$\begin{array}{l}\text { ESS:10-24 point } \\
\text { Moderate/High }\end{array}$} & \multirow[b]{2}{*}{ p } \\
\hline & & $\mathrm{n}$ & $\%$ & $\mathbf{n}$ & $\%$ & \\
\hline \multirow{3}{*}{ Age(year) } & $\leq 25$ years & 54 & 19.2 & 19 & 18.3 & \multirow{3}{*}{0.977} \\
\hline & $25-40$ years & 110 & 39.1 & 41 & 39.4 & \\
\hline & $\geq 40$ years & 117 & 41.6 & 44 & 42.3 & \\
\hline \multirow{4}{*}{ BMI $\left(\mathrm{kg} / \mathrm{m}^{2}\right)$} & Underweight & 53 & 18.9 & 7 & 11.7 & \multirow{4}{*}{$<0.001$} \\
\hline & Normal & 84 & 29.9 & 16 & 15.4 & \\
\hline & Overweight & 84 & 29.9 & 21 & 20.2 & \\
\hline & Obese & 60 & 21.4 & 60 & 57.7 & \\
\hline \multirow[t]{2}{*}{ Anxiety } & HAD-A $<10$ & 215 & 76.5 & 76 & 73.1 & \multirow[t]{2}{*}{0.573} \\
\hline & HAD-A>11 & 66 & 23.5 & 28 & 26.9 & \\
\hline \multirow[t]{2}{*}{ Depression } & HAD-D<7 & 88 & 31.3 & 18 & 17.3 & \multirow[t]{2}{*}{0.009} \\
\hline & HAD-D>8 & 193 & 68.7 & 86 & 82.7 & \\
\hline
\end{tabular}

BMI:Body Mass Index, HAD-A:Hospital Anxiety- Depression-Anxiety, HAD-D:Hospital Anxiety-Depression Depression, ESS: Epworth Sleep Scale

There was a statistically significant relationship between EDS score and BMI and depression status $(\mathbf{p}<\mathbf{0 . 0 0 1})$. It was seen that $57.7 \%(n=60)$ of 104 women with medium/high ESS scores were obese, $20.2 \%(n=21)$ were overweight and $82.7 \%$ $(n=86)$ were depressed (Table 2) (Figure 1).

According to the correlation and regression analysis between the BMI, HAD-A, HAD-D, and ESS scores; a moderately significant positive correlation was found between BMI and HAD-D and EDS scores $(\mathrm{r}=0.356, \mathbf{p}<\mathbf{0 . 0 0 1})$ (Table 3$)$. In presented study, as the BMI of the women increased, symptoms of depression and daytime sleepiness increased (Figure 1). For each 1.0 $\mathrm{kg} / \mathrm{m}^{2}$ increase in BMI, the incidence of EDS increases 1.1 times (95\% CI 1.03-1.26) (Figure 2).

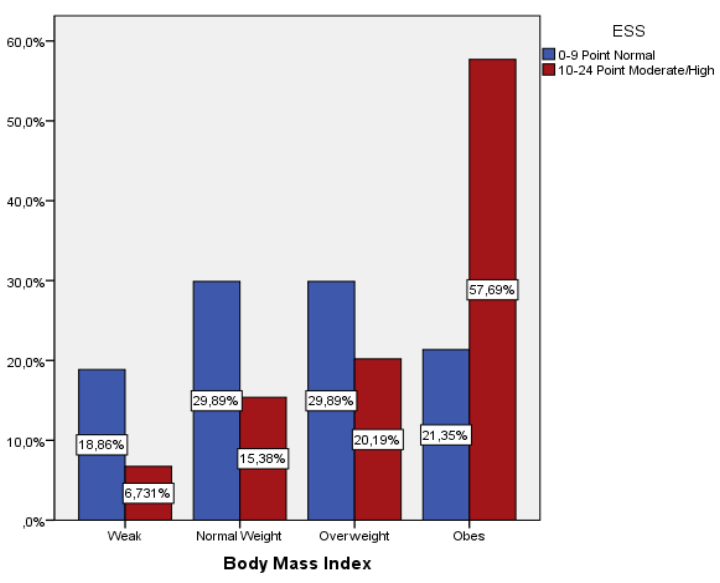

Figure 1: Comparison of BMI and ESS scores 
Table 3: Correlation of BMI, HAD-A, HAD-D, and ESS Scores

\begin{tabular}{|c|c|c|c|c|c|c|}
\hline & & Age & BMI & HAD-A & HAD-D & ESS \\
\hline \multirow[t]{2}{*}{ Age } & $\mathrm{r}$ & \multirow[t]{2}{*}{1} & & & & \\
\hline & $\mathrm{p}$ & & & & & \\
\hline \multirow[t]{2}{*}{ BMI } & $\mathrm{r}$ & $0.333 * *$ & \multirow[t]{2}{*}{1} & & & \\
\hline & $\mathrm{p}$ & $<0.001$ & & & & \\
\hline \multirow[t]{2}{*}{ HAD-A } & $\mathrm{r}$ & $-0.103 *$ & 0.027 & \multirow[t]{2}{*}{1} & & \\
\hline & $\mathrm{p}$ & 0.042 & 0.592 & & & \\
\hline \multirow[t]{2}{*}{ HAD-D } & $\mathrm{r}$ & $0.148 * *$ & 0.225 ** & $0.319 * *$ & \multirow[t]{2}{*}{1} & \\
\hline & $p$ & 0.003 & $<0.001$ & $<0.001$ & & \\
\hline \multirow[t]{2}{*}{ ESS } & $\mathrm{r}$ & -0.004 & $0.356 * *$ & $0.189 * *$ & $0.195 * *$ & \multirow[t]{2}{*}{1} \\
\hline & $p$ & 0.936 & $<0.001$ & $<0.001$ & $<0.001$ & \\
\hline
\end{tabular}

BMI:Body Mass Index, HAD-A:Hospital Anxiety- Depression-Anxiety, HAD-D:Hospital Anxiety-Depression Depression, ESS: Epworth Sleep Scale

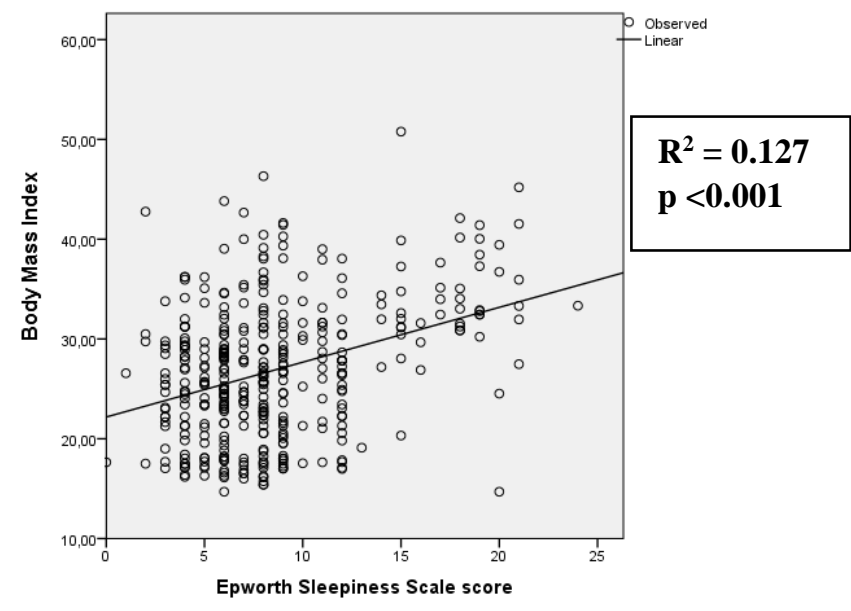

Graph 2: Linear regression analysis between BMI and ESS

\section{DISCUSSION}

Excessive daytime sleepiness (EDS) is characterized by an increased need for daytime sleepiness when an individual needs to be awake and active, and its prevalence in society is estimated to be as high as $18 \%{ }^{13}$. In this study where we aimed to investigate the effect of obesity on depression and daytime sleepiness in women, the frequency of EDS was found to be $9.4 \%$.

The mean score of ESS was found to be $8.50 \pm 4.4$ points. Mendoza et al. in a cohort study in 2015, the incidence of EDS was found to be $8.2 \%{ }^{14}$. Sonmez et al. in their study investigating sleep disorders in nurses in 2010, they found that the mean score of ESS was $4.97 \pm 3.9$ points and the frequency of EDS was $15.4 \%$. Shift working and rhythm disturbance have been reported to cause excessive daytime sleepiness ${ }^{15}$. The frequency of
EDS may have been lower because the majority of participants in our study were housewives or employees with daytime. In presented study, the frequency of EDS was higher in women with secondary school and below educated, married and housewives compared to single, highly educated and working women. Contrary to our findings, in a study conducted in middle-aged healthy women in the USA, no significant relationship was found between age, race, marital status, income level, menopause status and sleepiness. However, sleepiness was more common in patients with depression or anxiety, who had chronic disease, and who received treatment and had high BMI ${ }^{16}$.

There was no significant correlation between the age group of women aged 18-65 and EDS, but it was observed in the correlation analysis that the BMI and depression score increased with increasing age. EDS and depression were more common in the elderly ${ }^{17}$. In the wide communitybased studies of Bixler et al., the frequency of EDS was $8.7 \%$, and they found that sleepiness scores were equally distributed in men and women. In the study, they showed that EDS was less in patients between the ages of 30-75 and more in individuals over the age of 75 . The frequency of EDS increases dramatically in patients with BMI>28 $\mathrm{kg} / \mathrm{m}^{2}$. They found a significant relationship between patients receiving depression treatment and EDS $^{5}$. Obesity is associated with low quality of life, psychological discomfort and depression symptoms. In presented study, obese women with BMI $\geq 30.0 \mathrm{~kg} / \mathrm{m}^{2}$ had more depression and excessive daytime sleepiness than women who were weak and normal weight. Dixon et al. study of 1055 patients with BMI > 35 $\mathrm{kg} / \mathrm{m}^{2}$ found a correlation between high ESS and depression, age, quality of life, diabetes, male sex and smoking. They confirmed that increased age 
and high depression scores were associated with ESS $>10$ points with the binary logistic regression analysis ${ }^{8}$. Therefore, excessive daytime sleepiness in obese individuals is accompanied by symptoms of depression and poor quality of life. The relationship between EDS and the frequency of depression in overweight and obese individuals can be explained by physical inactivity, limited participation in daily activities and sedentary lifestyle. This cyclical relationship between EDS and physical inactivity can contribute to the onset of a clinically depressive mood.

In this presented study, more than half of those with moderate/high ESS scores were obese and the vast majority had depressive symptoms. In another study, in multivariate logistic regression analysis between BMI and EDS, it was found that obesity and moderate/severe sleep status $(\mathrm{ESS} \geq 12) \quad$ were positively significantly associated $^{18}$. In a community based study, it was found that depression was an important risk factor for excessive daytime sleepiness. This was followed by BMI, age, sleep time, smoking ${ }^{19}$. In a study conducted in Western Anatolia in 2012, the frequency of $\mathrm{EDS}$ was found to be $14.6 \%$, whereas for every $1.0 \mathrm{~kg} / \mathrm{m}^{2}$ increase in BMI, the EDS probability rate increased by 1.14 times $^{20}$. Similarly, the incidence of EDS increased by 1.1 times with every $1.0 \mathrm{~kg} / \mathrm{m}^{2}$ increase in BMI in the presented study. Differently, in a study of elderly patients, the incidence of EDS in obese increased by 2.5 times compared to those with non-obese ${ }^{8}$. In a metaanalysis analyzing 42 studies, a nonlinear relationship was found between the amount of weight loss and the change in daytime sleepiness, and losing weight improved the daytime sleepiness ${ }^{21}$.

Similarly, in a study on the relationship between irregular sleep and lifestyle factors such as obesity, diet and physical activity, EDS was found to be associated with obesity independent of diet and physical activity ${ }^{22,23}$.

In conclusion, these findings suggested that obesity was one of the causes of depression and excessive daytime sleepiness. As the level of obesity and depression increased, the level of EDS also increased. While obesity can be associated with depression through psychobiological mechanisms, EDS can be an early sign of depression. Treatment of obesity, depression and sleep disorders should be a part of public health policies. In particular, physicians working in primary care should identify the changeable risk factors in their patients and take precautions for them. Further studies are required to define for the early diagnosis of EDS.
Limitations of the study: There is no gold standard test method for measuring daytime sleepiness. In our current study, the participants may not have accurately reported their symptoms to the survey we used to detect EDS. More detailed tests should be done in the future to identify other determinants of EDS.

\section{REFERENCES}

1. WHO. Physical Status: The Use and Interpretation of Anthropometry. Report of a WHO Expert Committee, WHO Technical Report Series. 1995.

2. Satman I, Omer B, Tutuncu Y, et al. Twelveyear trends in the prevalence and risk factors of diabetes and prediabetes in Turkish adults. Eur J Epidemiol 2013;28(2):169-80.

3. Johns MW. A New Method for Measuring Daytime Sleepiness: The Epworth Sleepiness Scale. Sleep 1991;14(6):540-5.

4. Dixon JB, Dixon ME, Anderson ML. et al. Risk Factors and Chronic Disease Daytime Sleepiness in the Obese : Not as Simple as Obstructive Sleep Apnea. Obesity. 2007;15(10):2504-11.

5. Bixler EO, Vgontzas AN, Lin HM, Calhoun SL, Vela-Bueno A, Kales A. Excessive daytime sleepiness in a general population sample: The role of sleep apnea, age, obesity, diabetes, and depression. J Clin Endocrinol Metab. 2005;90(8):4510-5.

6. Sabanayagam C SA. Sleep duration and cardiovascular disease: results from the National Health Interview Survey. Sleep 2010;33(8):103742.

7. Gooneratne NS, Richards KC, Joffe M, et al. Sleep disordered breathing with excessive daytime sleepiness is a risk factor for mortality in older adults. Sleep 2011;34(4):435-42.

8.Dixon JB, Schachter LM, O'Brien PE. Polysomnography before and after weight loss in obese patients with severe sleep apnea. Int $\mathbf{J}$ Obes(Lond). 2005; 29(9):1048-54.

9.Chellappa SL, Schröder C, Cajochen C. Chronobiology, excessive daytime sleepiness and depression: Is there a link? Sleep Medicine 2009;10(5):505-14.

10.Zigmond AS, Snaith RP. The hospital anxiety and depression scale. Acta Psychiatr Scand 1983;67:361-70.

11.Aydemir O, Guvenır T, Kuey L, Kultur S. Validity and Reliability Study of Hospital Anxiety and Depression Scale Turkish Form. Turkish Journal of Psychiatry 1997;8 (4):280-7. 
12.Izci B, Ardic S, Firat H, Sahin A, Altinors M KI. Reliability and validity studies of the Turkish version of the Epworth Sleepiness Scale. Sleep Breath 2008;12(2):161.

13. Swanson LM, Arnedt JT, Rosekind MR et al. Sleep disorders and work performance: findings from the 2008 National Sleep Foundation Sleep in America poll. J Sleep Res 2011;20(3):487-94.

14. Mendoza FJ, Vgontzas AN, Kritikou I, Calhoun SL, Liao D, Bixler EO. Natural History of Excessive Daytime Sleepiness: Role of Obesity, Weight Loss, Depression, and Sleep Propensity. Sleep 2015;38(3):351-60.

15. Sonmez S, Ursavas A, Uzaslan E, et al. Sleep Disorders and Occupational Accident in Shift Work Nurses. Turk Toraks Derg 2010;11(3):1058.

16.Chasens ER, Twerski SR, Yang K, Umlauf MG. Sleepiness and health in midlife women: Results of the national sleep foundation's 2007 sleep in America poll. Behav Sleep Med 2010;8(3):157-71.

17. Lopes JM, Dantas FG, Medeiros JLA. Excessive daytime sleepiness in the elderly: association with cardiovascular risk, obesity and depression. Rev Bras Epidemiol 2013;16(4):8729.

18.De Araújo TA, Mota MC, Crispim CA. Obesity and sleepiness in women with fibromyalgia. Rheumatol Int 2014;35(2):281-7.

19. Theorell-Haglöw J1, Lindberg E JC. What are the important risk factors for daytime sleepiness and fatigue in women? Sleep 2006;29(6):751-7.

20. Gunes Z, Şahbaz M, Tugrul E, Günes H. Prevalence and risk factors for excessive daytime of sleepiness in rural western Anotolia (Turkey): The role of obesity and metabolic syndrome. Southeast Asian J Trop Med Public Health 2012;43(3):747-55.

21. Šiarnik P, Klobučníková, K Šurda P, Putala M, Śutovský $\quad$ S, Kollár $\quad$ B, Turčáni $\quad P$. Excessive Daytime Sleepiness in Acute Ischemic Stroke: Association With Restless Legs Syndrome, Diabetes Mellitus, Obesity, and SleepDisordered Breathing. J Clin Sleep Med. 2018;15;14(1):95-100.

22. Ng WL, Stevenson CE, Wong E, Tanamas S, Boelsen-Robinson T, Shaw JE Does intentional weight loss improve daytime sleepiness? A systematic review and meta-analysis. Obes Rev. 2017;18(4):460-475.

23. Maugeri A, Medina-Inojosa JR, Kunzova S, Agodi A, Barchitta M, Sochor O, Lopez Jimenez F, Geda YE, Vinciguerra M. Sleep Duration and Excessive Daytime Sleepiness Are Associated with Obesity Independent of Diet and Physical Activity. Nutrients. 2018;3;10(9). 